News, Notes and Queries

\title{
REFERENCES
}

1. Charcot's joint-affection ... ., Louisville med. News, I April, 1882, 13, 155 .

2. Locomotor ataxy and the late Mr. Stanley, Brit. med. F., 1882, i, 239-40.

3. Eve, F. S., Our museum and its associations, St. Barts. Hosp. Rep., 1881, 17, 165-93.

4. Stanley, E., On dislocations, especially of the hip joint, accompanied by elongation of the capsule and ligaments, Med. Chir. Trans., 1841, 24, 123-45.

5. Kelly, M., Neurogenic arthropathy-a critical review, Rheumatism, 1960, 16, 38-50.

6. Musgrave, W., De Arthritide Symptomatica Dissertatio, Exeter, Yeo and Bishop, 1703 , Pp. 222-4.

7. KeLLY, M., The first description of neurogenic arthropathy by William Musgrave (1 703), Bull. Hist. Med. (in press).

8. Obituary: Edward Stanley (1 791-1862), F.R.S., Brit. med. 7., 1862, i, 580.

9. Scudamore, G., $A$ Treatise on the Nature and Cure of Gout and Rheumatism, Philadelphia, Brown, 1819, p. 308.

10. Paget, Sir James, Memoirs and Letters, edited by one of his sons (Stephen Paget), London, Longmans, r 901 , p. 438.

I I. BRID g ES, R., Carmen elegiacium de Nosocomio Sti. Bartholomaei Londiniensi . . ad . . . ornatissimum virum Patricium Black, London, Bumpus, 1877.

12. Paget, ${ }^{10}$ loc. cit., pp. 40-r.

13. Paget, ${ }^{10}$ loc. cit., p. 46 .

14. Paget, ${ }^{10}$ loc. cit., p. 90.

15. PAGET, 10 loc. cit., p. 120.

16. KELLy, M., The Carmen Elegiacum de Nosocomio Sti. Bartholomaei of Robert Bridges, Med. Hist., 1963, 7, 186-7.

17. PAGET, 10 loc. cit., p. 142.

18. PAGE T, 10 loc. cit., p. 222.

19. Obituary: Edward Stanley, F.R.S., Lancet, 1862, i, 589-90.

MIGHAEL KELLY

\section{A CONNECTION BETWEEN GHARLES AND GILBERT WHITE}

One hundred and fifty years ago, in February 1813, Dr. Charles White, F.R.S., died at Sale Priory, in North Cheshire, the home of his family for several generations. He had retired not long before from his important practice in Manchester and the surrounding counties. He was probably the most celebrated surgeon and obstetrician outside London. He had played the principal part in founding both the Publick Infirmary (later the Manchester Royal Infirmary), where he was the leading surgeon from the age of 24, and in later years the Manchester and Salford Lying-in Charity, the forerunner of St. Mary's Hospitals. His father, Dr. Thomas White, had a very large midwifery practice in the rapidly growing town. His son joined him at an early age, working mostly among the poorer classes. Appalled by the mortality due to puerperal fever, he set himself to fight against the prejudice and ignorance of the times. The Dictionary of National Biography emphasises 'the revolution he effected in the practice of midwifery, which he rescued from semi-barbarism and placed on a rational and humane basis'. 


\section{Newes, Notes and Queries}

De Quincey, when a young man, knew him well. He was fascinated by the famous 'Manchester Mummy' in White's possession. A Miss Hannah Beswick had left a large bequest to White, stipulating that she was not to be buried for 100 years after her death. She had been obsessed by the fear of burial alive, a fate only narrowly averted in the case of a relative taken ill when travelling abroad. White embalmed the body, and eventually it lay for many years-in an oak coffin-on the roof of Sale Priory.

Memories and traditions were handed on when, some seventy years after the time of Charles White, the old house became the home of my grandparents (Megson). Miss Beswick's oak coffin - but not the mummy - was found in the barn. Many of the trees planted by Charles and his father Thomas had reached maturity. (Charles was a great tree-planter, and had written a treatise on forestry.) Later still, our own visits to our grand-parents were always exciting occasions! We heard of Dr. White at a very early age, and of course the story of Miss Beswick-and her ghost-exercised our imaginations, as did legends of the monks who had once maintained a priory on that site.

That there could be an unsuspected connection (although apparently no kinship) between the Manchester surgeon and his great contemporary Gilbert White of Selborne, occurred to me recently when I noticed in the Life and Letters of Gilbert White (by R. Holt-White) that Gilbert White expressed great pleasure on hearing in 1775 that his nephew John was apprenticed 'under a master of so much reputation'. This master is only vaguely identified by Holt-White as 'a surgeon, probably at Manchester'. It is tantalizing that the surgeon's name is nowhere mentioned in the published letters of Gilbert White, though they often reveal an approving and affectionate interest in his nephew John's activities at Manchester. Earlier, John White had been his uncle's pupil and companion at Selborne and was the 'useful amanuensis' in whose handwriting the publishers first received much of The Natural History of Selborne.

Inquiring in the first place at the Central Library in Manchester, I was confronted by a whole group of Manchester surgeons contemporary with Charles White; no doubt all had had apprentices, but their names had quite escaped official record! Then a valuable clue derived from an unpublished letter of Gilbert's, in John Rylands Library.

I was also kindly given access to much relevant material at the Medical Library at Manchester University. Here was clear evidence that a collection of Charles White's personal papers were extant in 1903, and that among his medical diplomas, family wills, estate maps, etc., were also 'Bundles of papers and letters regarding Mr. John White of Blackburn, apprentice to Dr. White'. This could very well be Gilbert's nephew John! His father was Vicar of Blackburn for eight years. I also found some letters of 1903 from a direct descendant of Charles White, and enquiries at that writer's home town led recently to interesting correspondence with the same family. But nothing was known of a connection with Gilbert White of Selborne, and I was informed that the personal papers of their ancester Charles were all lost in the last war! But I was kindly told of one remaining hope, in that a document bearing the autograph of Charles White had been sent by the family to America 'long before the war'- to Professor Harvey Cushing of Harvard University, who was interested in the English surgeons of the eighteenth century. 'It could have been an indenture of an apprentice', the sender thought. (But Charles White must have had many apprentices in his time.)

My enquiries to Harvard received most courteous attention, and led on to the Cushing Library at Yale, where the professor taught at a later date. With prompt 


\section{News, Notes and Queries}

efficiency the now frail document was found in the library which he founded there, and a photostat copy sent to me. The first few lines were at once reassuring!

Whereas by Indenture dated this Day John White the Son of The Reverend Mr. John White of Blackburn was bound an apprentice to Mr. Charles White of Manchester Surgeon for the Term of Seven Years from the date hereof. Nevertheless it was agreed before the Execution of the said Indenture, and it is hereby also declared and agreed between and among the said Parties, that the said John White the apprentice shall be at Liberty at the Expence of his Father, or at his own Expence to go and reside the last year of the said Term where and with whom he shall please uncontrolled by and without any Restraint from the said Charles White his Executors Administrators or assigns, The said Indenture or any Thing therein contained to the Contrary notwithstanding - Witness their Hands the sixteenth Day of June 1775.

Signed in the Presence of

Jo. Chippindall

I6 June 1775

$$
\begin{aligned}
& \text { J. WHITE } \\
& \text { J. WHITE } \\
& \text { c. WHITE. }
\end{aligned}
$$

Young John White was then only sixteen years old. Born when his father was Chaplain to the Garrison at Gibraltar, he was known as 'Gibraltar Jack' in the family circle. After his long apprenticeship to Charles White, he set up as a country doctor at Alton within easy reach of his uncle at Selborne. He moved soon afterwards to a practice in Salisbury, where he was surgeon to the Infirmary. Later he spent some years in the East Indies.

Of any meeting between Gilbert White and Charles I found no real evidence. But it is certain that the apprentice John would appreciate and remark upon their similar interests, for few had known and shared his uncle's interests as he had. Charles was adding to his notable collection of trees at Sale, and now John would see him recording their growth-with the scientific accuracy of Gilbert's own observations at Selborne. (They each planted the new Luccombe variety of oak in the 1770 s.)

But of course their mutual interests would have extended far into the realms of natural science, and each would have been complemented by the other's lively mind. Alas for the family papers lost in the war!

ROBERT C. CASH

\section{MEDICAL HISTORY IN MODERN INDIA}

[Dr. Douglas Guthrie, who has recently returned from a visit to India, where he met India's leading medical historians and saw the chief centres of teaching and research in the history of medicine, has contributed this note at our request. Ed.]

PeRHAPs in no other country is an interest in the history of medicine more keenly felt that in India today. Since 1947, when India's 400 million inhabitants emerged as an independent nation, this interest has grown and extended, having already existed during many centuries. We of the West are accustomed to regard Greece as the original home of much of our culture, and as the main source of our medical knowledge. India has quite a different history and heritage. The Hindu god of medicine, Dhanwantari, takes the place of Aesculapius in the Indian mind, while Hindu physicians trace their medical ancestry back to Charaka and Susruta, and accord to such sages the honours which we attribute to Hippocrates and Galen.

When viewed in a modern light, the divergence between the medical history of Greece and that of India becomes much wider. Greek Medicine survives today only as a dim conception, taking no prominent place in current medical practice. Ancient Indian Medicine, on the other hand, is still a living reality, which may be seen at 